\title{
An assessment of climate, weather, and fuel factors influencing a large, destructive wildfire in the Knysna region, South Africa
}

Tineke Kraaij $^{{ }^{*}}$ (D), Johan A. Baard ${ }^{2}$, Jacob Arndt ${ }^{3}$, Lufuno Vhengani ${ }^{4}$ and Brian W. van Wilgen ${ }^{5}$

\begin{abstract}
Background: In June 2017, wildfires burned 15000 ha around the town of Knysna in the Western Cape, destroying $>800$ buildings, $>5000$ ha of forest plantations, and claiming the lives of seven people. We examined the factors that contributed to making this one of the worst fires on record in the region.

Results: One third of the area that burned was in natural vegetation (mainly fynbos shrublands), and more than half was in plantations of invasive alien (non-native) pine trees, or in natural vegetation invaded by alien trees. We used satellite imagery to assess burn severity in different land cover types by comparing pre- and post-fire images to estimate biomass consumed. We used daily weather data from two weather stations to calculate fire danger and drought indices over 70 years, and compared the fire weather conditions during the 2017 Knysna fires to the long-term weather record. The amount of biomass consumed was significantly higher in plantations of invasive alien trees, and in fynbos invaded by alien trees, than in uninvaded fynbos, providing support for the contention that invasion by alien trees increases the impact and difficulty of control of wildfires. Fire danger indices on the days of the fires were in the top 0.1 to $0.2 \%$ of days in the historic record, indicating that fire weather conditions were extreme but not unprecedented. The fires were preceded by a prolonged drought, and 18-month running means for two drought indices were the highest on record.

Conclusion: The severity of the fires was exacerbated by very high fire danger conditions, preceded by an unprecedented drought, and further worsened by the conversion of natural fynbos vegetation to plantations, and invasion of vegetation by alien trees. Historical fire suppression also resulted in fuel buildups, further aggravating the problem of fire control, while residential development within and adjacent to fire-prone areas increased the risks faced by residents. Our results support calls to control invasive alien plants, reduce commercial planting of invasive alien trees, strictly regulate development in areas of high fire risk, and maintain awareness of the need for fire-wise practices.
\end{abstract}

Keywords: dNBR, Drought, Fire severity, Fynbos, Invasive alien plants, Sentinel 2A, Thicket, Urban-wildland interface

\footnotetext{
*Correspondence: tineke.kraaij@mandela.ac.za

${ }^{1}$ School of Natural Resource Management, Nelson Mandela University, Private

Bag X6531, George 6530, South Africa

Full list of author information is available at the end of the article
} 


\section{Resumen}

Antecedentes: En junio de 2017, incendios de bosques quemaron 15000 ha alrededor del pueblo de Knysna en la región del Cabo Occidental de Sudáfrica, destruyendo $>800$ edificios, $>5000$ ha de forestaciones y quitando la vida a siete personas. Examinamos en este trabajo los factores que contribuyeron a hacer de éste, uno de los peores incendios registrados en la región.

Resultados: Un tercio del área quemada estaba compuesta de vegetación natural (fundamentalmente de matorrales de "Fynbos") y más de la mitad con plantaciones de pinos invasores (no nativos) o con vegetación natural invadida por árboles exóticos. Usamos imágenes satelitales para determinar la severidad del incendio en diferentes tipos de coberturas vegetales, mediante la comparación de imágenes pre- y post-incendio para estimar la biomasa consumida. Usamos datos meteorológicos diarios de dos estaciones meteorológicas para calcular el peligro de incendio, e índices de sequía de más de 70 años, y comparamos las condiciones meteorológicas que afectaron al fuego durante los incendios de Knysna de 2017 con aquellas correspondientes a registros históricos. La cantidad de biomasa consumida fue significativamente mayor en plantaciones de especies exóticas invasoras y en matorrales de Fynbos invadidos por árboles exóticos que en matorrales de Fynbos no invadidos, lo que apoya el argumento de que la invasión por árboles exóticos incrementan el impacto y la dificultad de controlar estos incendios. Los índices de peligro de los días de los incendios estuvieron entre el 0,1 y 0,2\% más alto en el registro histórico, indicando que las condiciones meteorológicas eran extremas aunque no sin precedentes. Los incendios fueron precedidos por una sequía prolongada, y las medias de dieciocho meses para dos índices de sequía fueron las más altas que se tengan registros.

Conclusiones: La severidad de los incendios fue exacerbado por condiciones muy altas de peligro, antecedida por una sequía sin precedentes y también agravada por la conversión de los matorrales de Fynbos en plantaciones y la invasión de la vegetación nativa por árboles exóticos. La supresión histórica de incendios también resultó en incrementos de biomasa combustible, agravando luego el problema del control del fuego, mientras que el desarrollo residencial dentro y en las adyacencias a áreas proclives al fuego incrementó el riesgo afrontado por los residentes. Nuestros resultados apoyan el reclamo para controlar plantas invasoras, reducir las plantaciones comerciales de árboles exóticos invasores, regular estrictamente el desarrollo de áreas con alto riesgo de incendio, y mantener la concientización sobre la necesidad de llevar a cabo prácticas sensatas de manejo del fuego.

\section{Background}

The incidence of large, damaging wildfires is a significant and growing problem in many parts of the world (Syphard et al. 2017). In fire-prone regions such as California, Australia, Spain, Portugal, and Greece, these fires have resulted in the deaths of many people, killed livestock and wildlife, and destroyed thousands of buildings, frequently in a single fire event (Quinn 1994, Riggan et al. 1994; San-Miguel-Ayanz et al. 2013; Williams 2013). The extent, severity, and impact of these fires have been influenced by a number of factors, including the occurrence of extreme weather conditions (sometimes attributed to global climate change), a buildup of fuel often resulting from extended periods of fire suppression, increased sources of ignition that are linked to growing human populations, expansion of the urban-wildland interface, and invasion by flammable alien (non-native) plants (Scott et al. 1998, Radeloff et al. 2005, Pauchard et al. 2008, San-Miguel-Ayanz et al. 2013, Keeley and Syphard 2017). While climate change is predicted to worsen fire conditions (and is often blamed for increased fires) in many parts of the world, growing human presence may override climatic controls of fire activity in some areas (Syphard et al. 2017).
Wildfires also occur in South Africa's fynbos shrublands, but they have tended to be less severe in terms of damage and loss of life when compared to fires in several other parts of the world (San-Miguel-Ayanz et al. 2013, Vonberg and Cotovio 2017). However, in the winter of 2017, wildfires (hereafter, the 2017 Knysna Fires) burned approximately 15000 ha over four days around the towns of Knysna, Sedgefield, and Plettenberg Bay, along the southern Cape coast of South Africa, resulting in the deaths of seven people and the destruction of $>5000$ ha of commercial forestry plantations and over 800 buildings. The destruction made headlines across the country, but the likelihood of such a disaster had been foreseen for some time. For example, Cowling et al. (2009) and Kraaij et al. (2011) warned that ongoing neglect of the holistic fire management in the broader region would inevitably result in major damaging wildfires. Later, a study by Forsyth and Le Maitre (2015) found that wildfire poses a high or extreme risk to more than half of the 3700 buildings in which people live or work in Plettenberg Bay.

In the aftermath of the 2017 Knysna Fires, speculation was rife regarding the cause of the fires and the factors 
influencing their severity. These included that the extent of the fires was, or was not, due to climate change (Gosling 2017, Vegter 2017); that the fire was fuelled by plantations and stands of invasive alien trees; or, alternatively, by "very old fynbos" (i.e., native shrubland vegetation that had not been burned for a long time), and not by invading alien plants (De Ronde 2017); that high levels of damage were due to uncontrolled development along the wildland-urban interface (G.G. Forsyth, Council for Scientific and Industrial Research, Stellenbosch, South Africa, personal communication); that extreme drought or weather conditions led to uncontrollable fires (Stehle 2017); or that a number of factors (drought, flammable vegetation, topography, and hot and windy weather) came together simultaneously to produce "the perfect inferno" (Preston 2017). While each of the proposed influencing factors may well have played a role, there is little in the way of documented evidence to support any of these. It is nonetheless important to investigate and record these factors as accurately as possible, both to better understand and prepare for similar events in future, as well as to resolve potential disputes around liability for damage (cf. Van der Merwe 2017).

In this paper, we assessed the climatic, weather, and fuel factors that influenced the severity of the 2017 Knysna Fires. We compared the severity of weather conditions on the days of the fires, and climatic conditions preceding the fires, to the long-term weather record to assess the longterm frequency of occurrence of such conditions. We also used remote sensing to compare biomass consumed and completeness of burn in a range of natural or transformed vegetation types to assess whether conversion of natural vegetation to plantations of invasive alien trees, and invasion of natural vegetation by these and other alien trees or shrubs, had an influence on the intensity of fires.

\section{Methods}

\section{Study area}

The study area is situated along the southern Cape coast of South Africa. It is centered on the town of Knysna, and bounded by the towns of Sedgefield in the west and Plettenberg Bay in the east, with the foothills of the Outeniqua Mountains to the north and the Indian Ocean to the south (Fig. 1). Much of this area is within or adjacent to the 140 000 ha Garden Route National Park (Kraaij et al. 2011). The vegetation of the area is flammable fynbos shrublands, interspersed with smaller areas of Afrotemperate forest and thicket vegetation that seldom burns (Geldenhuys 1994). A mixture of fynbos and thicket occurs along the coast (often on dune sands) where fire suppression over the past 50 to70 years has resulted in the dominance of thicket (Kraaij et al. 2011). For the conservation of fynbos, moderate to high-intensity fires at 10- to 20-year intervals are optimal (Kraaij et al. 2013a, Kraaij and van Wilgen 2014). Plantations of invasive alien pine (Pinus pinaster Aiton and $P$. radiata D. Don) trees have fragmented and replaced large tracts of fynbos (Kraaij et al. 2011). The mixture of fire-dependent fynbos and fire-sensitive pine plantations has led to two major management problems: (1) the need to protect the plantations from fire, and (2) invasion of natural vegetation adjacent to plantations by fire-adapted pines. Fires kill trees in plantations, but they also drive invasion away from plantations by triggering seed release, dispersal, and germination. As a result, Pinus species are estimated to occur over $>90 \%$ of the Garden Route National Park's fynbos vegetation at various densities, and additional invasions by Australian Acacia Mill. and Eucalyptus L'Hér. species cover a further $29 \%$ and $14 \%$, respectively (Vromans et al. 2010). More than 244 species of alien plants occur in the area (Baard and Kraaij 2014), and

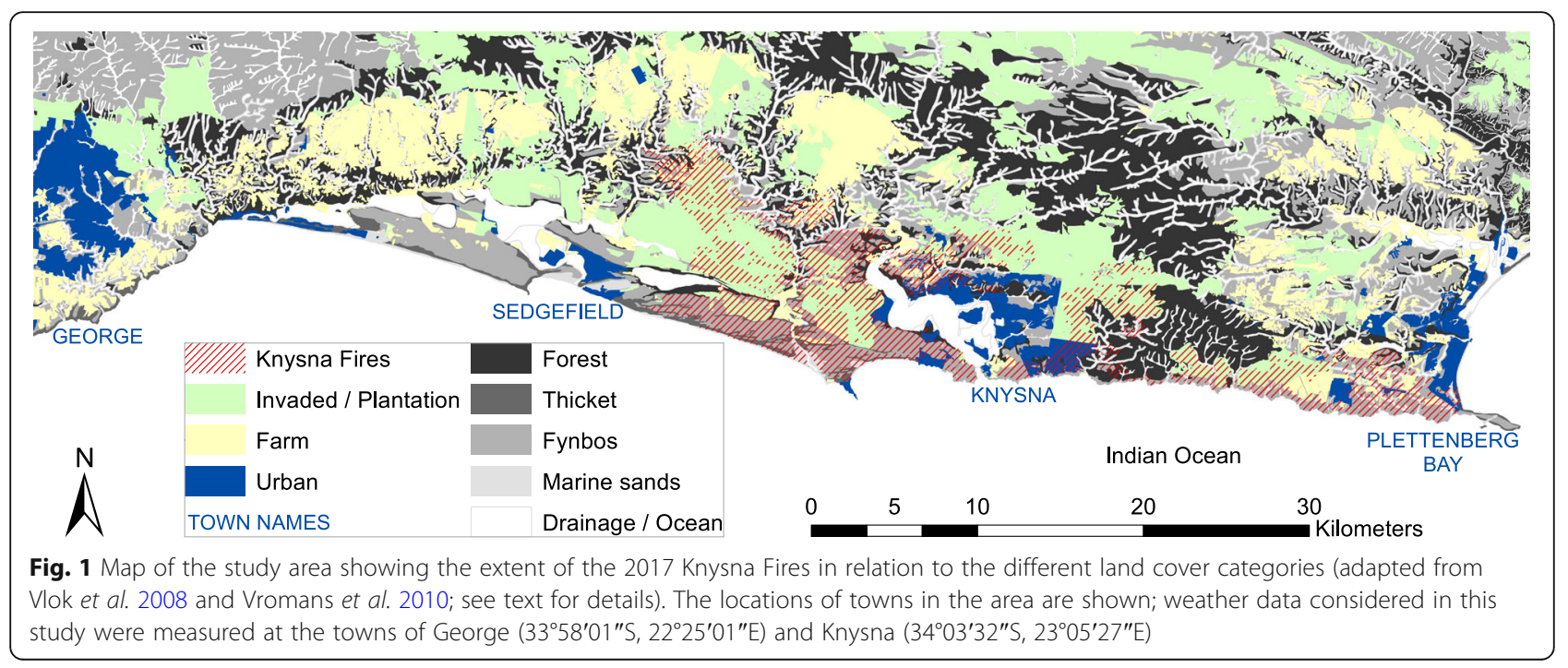


major efforts are underway to manage invasive alien plants (Kraaij et al. 2017).

The climate is temperate with mean minimum and maximum temperatures ranging from 7 and $19{ }^{\circ} \mathrm{C}$ in June to 15 and $26{ }^{\circ} \mathrm{C}$ in January (Bond 1981). Rainfall is aseasonal, with a mean annual rainfall of $\sim 875 \mathrm{~mm}$ (Kraaij et al. 2013b). Lightning occurs any time of the year and at a density of $<2$ flashes $\mathrm{km}^{-2} \mathrm{yr}^{-1}$ (Kraaij et al. 2013b). Hot, dry katabatic winds (known locally as bergwinds) occur in autumn and winter, and are associated with high fire danger conditions (Southey 2009, Kraaij et al. 2013b). Although mean daily fire danger is higher in winter, fires occur throughout the year (Kraaij et al. 2013b, Kraaij et al. 2013c).

\section{Data collection and analysis Areas burned}

The area burned by the fires between 7 and 10 June 2017 was digitized off Landsat-TM imagery (following methodology similar to that of Bowman et al. 2003) of 3 September 2017 in ArcGIS version 10.4 (Esri, Redlands, California, USA). The burn scar was intersected with land cover layers (derived from the vegetation map of Vlok et al. 2008 and the transformation map of Vromans et al. 2010, both mapped at 1:50 000 scale during the mid 2000s) to derive areas burned in each land cover category (Fig. 1). Land cover was divided into Natural (native vegetation in a pristine or near-pristine state [i.e., the "natural" category of Vromans et al. 2010]) or Altered (areas no longer in a natural state [i.e., the remaining categories of Vromans et al. 2010]). Natural vegetation was subdivided into fynbos (mediterranean-climate shrublands), thicket (dense shrublands including succulent plants), forest (Afrotemperate forest with tall trees and a sparse understorey), drainage (streambank and riparian vegetation, and open water dams), and marine (largely coastal sand dunes) (after the biome classification of Vlok et al. 2008). Altered areas were subdivided into invaded natural vegetation (areas transformed or degraded by dense infestations of invasive alien plants [i.e., the categories "alien transformed," "heavy alien degraded," and "degraded" of Vromans et al. 2010]), plantations (afforested with alien Pinus or Eucalyptus species), farms (irrigated crop agriculture or pastures, and farm infrastructure), and urban areas (categorized as such by Vromans et al. 2010).

\section{Burn severity}

Sentinel-2A and -2B suites of satellites (Drusch et al. 2012, Malenovský et al. 2012) enable mapping of fire effects at a spatial resolution of 10 or 20 meters, and burn severity (defined as the change in organic matter in an ecosystem due to a fire; Keeley 2009) can be derived by comparing sequential satellite images taken over time (López García and Caselles 1991, Key and Benson 1999,
Miller and Thode 2007). One index developed to map burn severity is the normalized burn ratio (NBR), computed as the difference between near infrared (NIR) and shortwave infrared (SWIR) reflectance divided by their sum (Eq. 1; López García and Caselles 1991, Key and Benson 1999):

$$
N B R=\frac{N I R-S W I R}{N I R+S W I R}
$$

Depending on the particular aspect of interest, variations of the NBR may be used for different purposes (Miller and Thode 2007, Hall et al. 2008, Miller et al. 2009). Our objective was to compare biomass consumed and completeness of burn, respectively, among land cover categories. Both of these are measures of burn severity (Keeley 2009), but we deliberately distinguished between biomass consumed and completeness of burn as they provide different information about burn severity. We used the differenced normalized burn ratio (dNBR, calculated by subtracting post-fire NBR from pre-fire NBR; Eq. 2) to produce a quantitative measure of absolute change in biomass (Miller and Thode 2007), hereafter, biomass consumed.

$$
d N B R=N B R_{\text {pre }}-N B R_{\text {post }}
$$

We used the relative differenced normalized burn ratio (RdNBR; Eq. 3) to assess the completeness of fuel consumption, hereafter, completeness of burn.

$$
R d N B R=\frac{N B R_{\text {pre }}-N B R_{\text {post }}}{\sqrt{a b s\left(N B R_{\text {pre }}\right)}}
$$

RdNBR normalizes dNBR to remove the effect of the pre-fire vegetation condition or type ( quantity of biomass; Miller and Thode 2007), and thus represents a proportional, rather than an absolute, measure of fuel consumption.

Sentinel-2A and -2B level-1C images from before and after the fire (15 March 2017 and 14 June 2017, respectively) were obtained from the Sentinel Scientific Data Hub (Malenovský et al. 2012). These images were atmospherically corrected using sen2cor (Müeller-Wilm 2016), which is a Python-based system for processing Sentinel-2 level$1 \mathrm{C}$ to level-2A. The corrected images were used to generate $\mathrm{dNBR}$ and RdNBR rasters at a resolution of $20 \mathrm{~m}$, and converted to point data in ArcGIS. Values per pixel for biomass consumed and completeness of burn were then extracted for each land cover category. These variables did not conform to normality, so we used the Kruskal-Wallis test followed by multiple comparisons of mean ranks to assess differences in biomass consumed and completeness of burn between land cover categories. Statistical analyses were done in Statistica (Dell Inc., Tulsa, Oklahoma, USA). 


\section{Weather and fire danger indices}

We obtained daily weather data from the town of George for the period 1943 to 2017 (George is $30 \mathrm{~km}$ west of the area burned in the 2017 Knysna Fires; Fig. 1), and from Knysna for the period 1997 to 2017. We used the McArthur Forest Fire Danger Index (Noble et al. 1980) to calculate daily fire danger indices (FDIs) from temperature, relative humidity, rainfall, and wind speed (Noble et al. 1980). The input data were recorded at 1400 hours each day (Kraaij et al. 2013b), as data at this time approximate daily maximum temperature, minimum relative humidity, and wind speed when wind is usually at its strongest. Total rainfall over the past 24 hours was also noted at 1400 hours. The McArthur Forest Fire Danger Index incorporates a drought factor (DF), and the Keetch Byram Drought Index (KBDI). These are stand-alone indices of the cumulative effect of seasonal drought on fire potential. DF is an index between 0 and 10, with 10 representing the driest conditions. The KBDI provides an estimate of the amount of precipitation (in $\mathrm{mm}$ ) needed to bring the soil back to saturation. It is infinitely cumulative (open-ended at the top of the range; Keetch and Byram 1968, Noble et al. 1980) and thus potentially more useful for identifying extreme drought conditions. Kraaij et al. (2013b) characterized FDI for these same weather stations up until 2010; we have since extended the analysis to August 2017. We calculated frequency distributions for long-term series of daily FDI, KBDI, DF, temperature, relative humidity, and wind speed. Values of each variable for each day (6 to 11 June) during the 2017 Knysna Fires were compared to the long-term record to assess the relative frequency of occurrence of similar weather in the past. We also calculated 6-, 12-, 18-, and 24-month running means of FDI, DF, KBDI, and monthly rainfall to examine the severity of weather conditions leading up to, and during, the 2017 Knysna Fires for the data from George, as the record was sufficiently long to justify this. To do this, we calculated the mean for each variable for the month, and used these monthly means to calculate running means of average monthly conditions.

\section{Results}

\section{Areas burned}

The 2017 Knysna Fires burned 14958 ha, of which one third was composed of natural vegetation, with the remainder in the altered category (Table 1). Most (72\%) of the natural vegetation that burned was fynbos shrublands, accounting for almost a quarter of the total area burned. Of the land in the altered category, most (78\%) was either commercial plantations of invasive alien trees $(52 \%)$ or other land invaded by alien plants $(26 \%)$. A relatively small proportion of the burned area was natural forests $(4 \%)$ or thicket $(2 \%)$. Although these vegetation types are normally fire resistant (i.e., do not burn
Table 1 Areas burned in five natural and four altered land cover categories in the Knysna region, South Africa, in June 2017

\begin{tabular}{lll}
\hline Land cover category & Area burned (ha) & Total burned area (\%) \\
\hline Natural & 4974 & 33 \\
Fynbos & 3581 & 24 \\
Thicket & 323 & 2 \\
Forest & 570 & 4 \\
Drainage & 339 & 2 \\
Marine (dune sands) & 161 & 1 \\
Altered & 9984 & 67 \\
Invaded natural vegetation & 2532 & 17 \\
Plantation & 5259 & 35 \\
Farm & 1437 & 10 \\
Urban & 756 & 5 \\
Total & 14958 & 100 \\
\hline
\end{tabular}

See text for a description of the land cover types

readily; van Wilgen et al. 1990), they can burn under extreme weather conditions (Fig. 2).

\section{Burn severity}

Biomass consumed (which we approximated using dNBR) differed significantly between land cover categories $\left(H_{8,387027}=22384, P<0.001\right)$, with almost all categories differing significantly from each other (Fig. 3). Biomass consumed was $13 \%$ higher in invaded natural vegetation than it was in natural fynbos ( $\mathrm{dNBR}$ values of 0.68 and 0.60 , respectively), and $8 \%$ higher in plantations than it was in natural fynbos (dNBR values of 0.65 and 0.60 , respectively). Although biomass consumed was also high in natural thicket and forest, only a small area of these vegetation types actually burned during the fires $(2 \%$ and $4 \%$ of all burned area, respectively; Table 1 ; Fig. 1). Completeness of burn ( proportionate fuel consumption, approximated using RdNBR) also differed significantly between land cover types $\left(H_{8,387027}=16361\right.$, $P<0.001$ ), with most categories differing significantly from each other (Fig. 3). In terms of completeness of burn, this was highest in fynbos (RdNBR of 1.2; Fig. 3), and somewhat lower in invaded natural vegetation and plantations (RdNBR values of 1.08 and 1.02, respectively). However, despite a lower completeness of burn in invaded vegetation and in plantations, compared to natural fynbos, the biomass consumed was higher, as both of the altered land cover types have substantially higher biomass than natural shrublands (Versfeld and van Wilgen 1986; Fig. 2).

\section{Fire danger weather and drought}

Daily weather conditions associated with the 2017 Knysna Fires were most severe on 6 June (the day before the fire started) at George and Knysna. High temperatures and low relative humidity prevailed on this day, followed by 


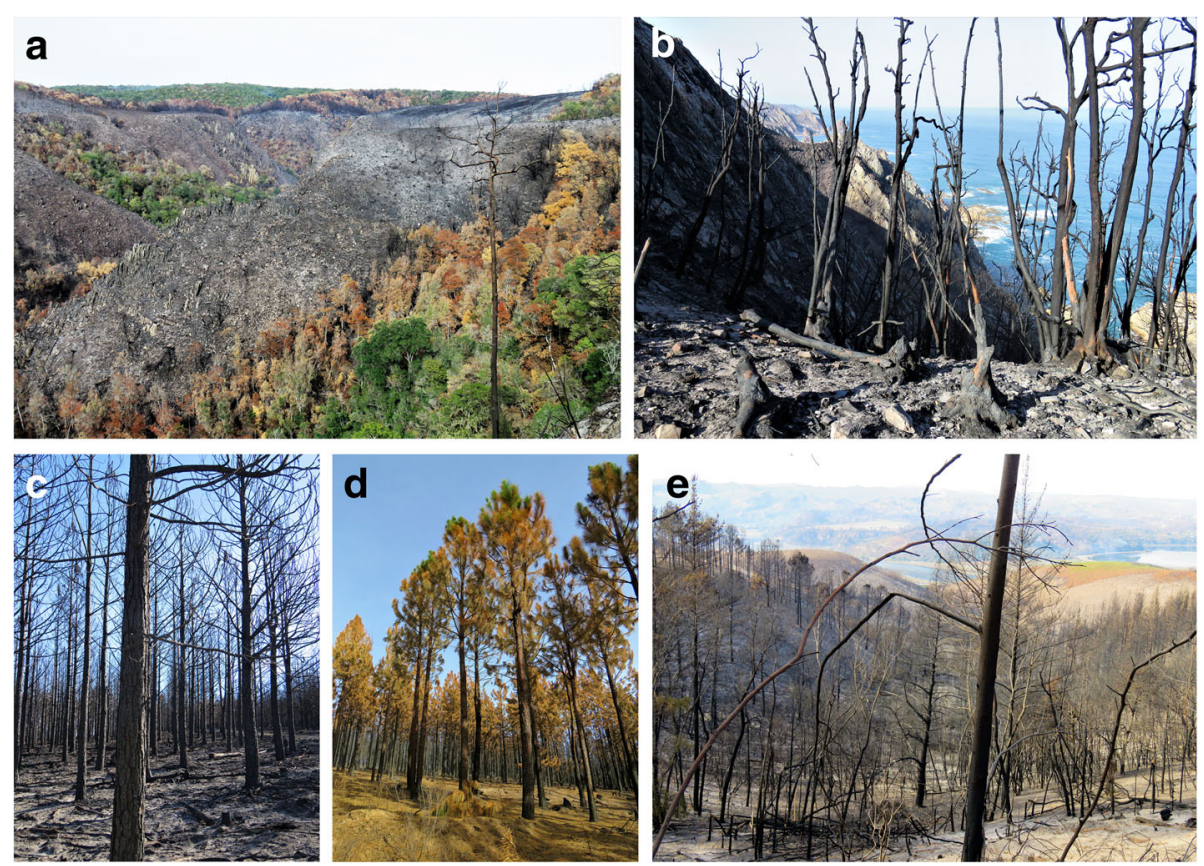

Fig. 2 Variation in burn severity (considering quantity of biomass consumed and completeness of burn) due to fuel differences among and within land cover categories: a fynbos (grey slope in midground) burned completely, and indigenous forest only patchily (green is unburned forest and brown is scorched forest); b coastal thicket burned completely; c pine plantation burned completely; $\mathbf{d}$ pine plantation burned incompletely; and e dense infestation of invasive alien plants burned completely

high wind speeds the next day (Table 2). FDI on 6 June was categorized as very high (FDI > 25; Noble et al. 1980), and equivalent (or worse) fire danger conditions occurred on approximately $0.10 \%$ of days in recorded history at George (since 1943), and on $0.05 \%$ of days in Knysna (since 1997). This is akin to a probability of occurrence of roughly one day every three years at George, and one day every six years at Knysna. Relative humidity was very low on 6 June and wind speed very high on 7 June at Knysna, having only occurred on $0.08 \%$ of days in recorded history. Drought indices at George and Knysna on the days of the fires had only occurred on $<1 \%$ of days in recorded history (Table 2). The KBDI at Knysna at the time was particularly high, with $150 \mathrm{~mm}$ of rainfall required to bring the soil back to saturation.

Running means for the fire danger index, drought indices, and rainfall revealed a buildup of high average conditions in the months prior to the 2017 Knysna Fires (Fig. 4). Running means calculated over 18 months yielded the most pronounced results. Eighteen-month running means of FDI ending mid 2017 were the second highest in recorded history at George. In terms of drought conditions preceding the fire, 18- (and 24-) month running means of DF and KBDI ending mid 2017 were the highest in recorded history at George. In addition, 18-month running means of monthly rainfall ending mid 2017 were the second lowest in recorded history at George. This indicated a buildup of dry conditions that was worse than any time in the past 70 years.

\section{Discussion}

The role of vegetation as fuel

The nature of the fuel complexes in the study area played an important role in determining the severity of the 2017 Knysna Fires. A policy of regular prescribed burning was practiced by the Department of Forestry in the 1970s and 1980s, with the dual goals of rejuvenating the fire-dependent vegetation and reducing fuel loads (Bands 1977, van Wilgen 2009). However, these practices were essentially halted in the late 1980s, and fire management shifted to a focus on fire suppression to protect forestry plantations and residential developments (van Wilgen 2009, Kraaij et al. 2011). As a result, substantial fuel buildups occurred in natural vegetation. For example, 37 years of protection of fynbos vegetation from fire resulted in an increase in fuel loads (quantity of aboveground biomass that will burn) from $2 \mathrm{t} \mathrm{ha}^{-1}$ in regularly burned vegetation to $7 \mathrm{t} \mathrm{ha}^{-1}$ (van Wilgen 1982). In addition, invasion of these areas can further increase fuel loads by 50 to $60 \%$ (van Wilgen and Richardson 1985). Large tracts of natural vegetation have also been systematically converted to plantations of Pinus and Eucalyptus species. Such changes increase aboveground biomass from 3 to $4 \mathrm{t} \mathrm{ha}^{-1}$ to $20 \mathrm{t} \mathrm{ha}^{-1}$ (Le Maitre et al. 1996). Given 

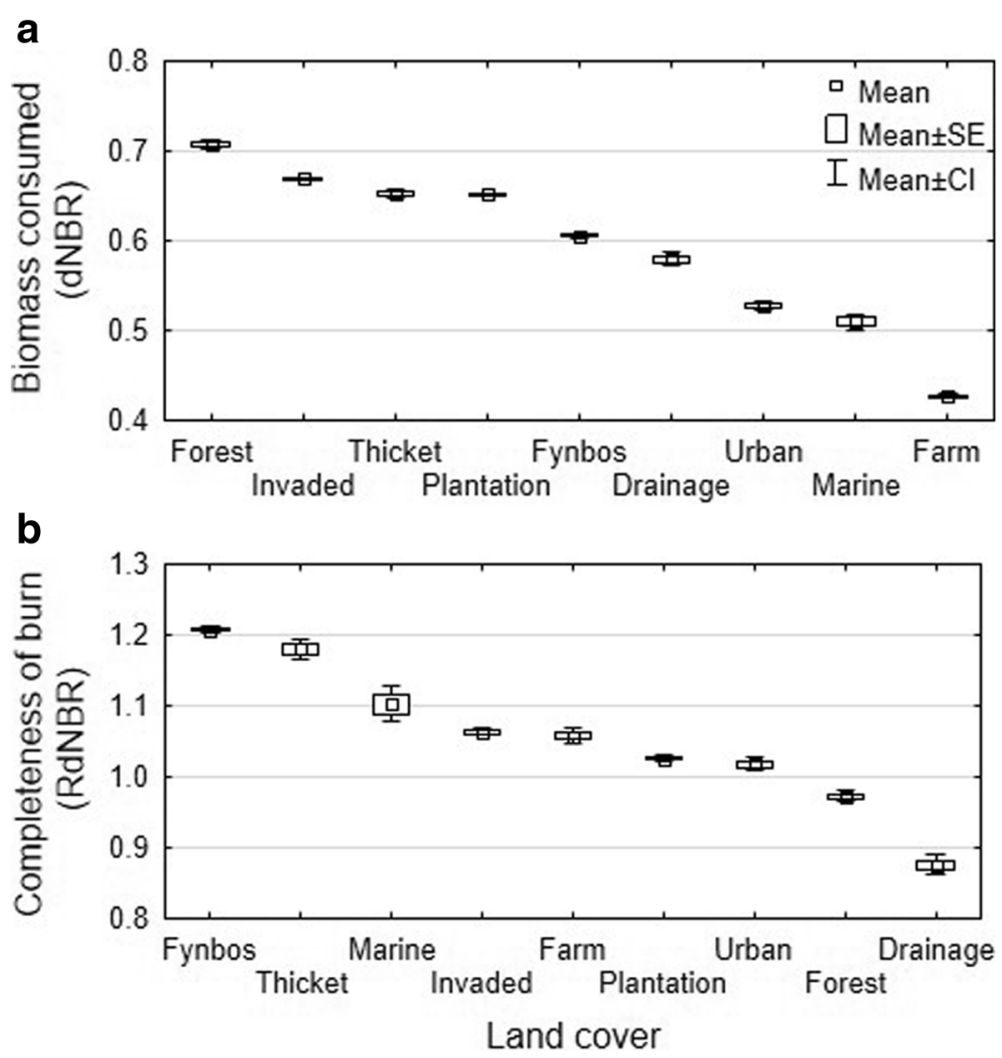

Fig. 3 Proxy measures for (a) the quantity of biomass consumed (based on the differenced Normalized Burn Ratio, dNBR), and (b) completeness of burn (completeness of fuel consumption, based on the Relative differenced Normalized Burn Ratio, RdNBR), in four altered and five natural land cover types, following fires in the Knysna region, South Africa, in June 2017. See text for a description of the land cover categories. SE = standard error; $\mathrm{Cl}=95 \%$ confidence interval

that more than two thirds of the area that burned was in one of these altered conditions, it is clear that fuel loads must have been substantially increased compared to earlier situations in which the landscape would have been dominated by more regularly burned, uninvaded natural vegetation. In addition, the human population in the area has grown substantially over the past decades. For example, Knysna's population grew by over 70\%, from 43000 to 74000 people, over the past 20 years (S. Neethling, Knysna Municipality, Knysna, South Africa, personal communication). This has been accompanied by increases in residential and rural development, creating an ever-increasing extent of the urban-wildland interface. High fuel loads around these developments would have further increased the damage done by fires.

\section{Effects of invasive alien plants on burn severity}

Invasion of natural ecosystems by alien plants can change the structure and biomass of vegetation, thereby increasing or decreasing aspects of the fire regime such as the frequency, intensity, and extent of fires (Brooks et al. 2004, Mandle et al. 2011). Additional fuel resulting from invasion would support fires of higher intensity and severity, which in turn would increase the damage done by fires, as well as the difficulty of controlling fires (Keeley 2009, San-Miguel-Ayanz et al. 2013). Although the principles behind this phenomenon have been understood for some time (Brooks et al. 2004), there is very little in the way of documented impacts of woody invasive species on fire intensity or severity (Mandle et al. 2011), particularly in South Africa. Van Wilgen and Richardson (1985) found that invasion of fynbos shrublands by the alien shrubs Hakea sericea Schrad. \& J.C.Wendl. and Acacia saligna (Labill.) Wendl. increased fuel biomass by between 50 and $60 \%$, but that this could not be shown to increase fire intensity in an existing fire behavior prediction model. These authors concluded that shortcomings in the model prevented the accurate simulation of high-intensity fires that were known to occur in invaded stands under severe fire weather conditions. Such fires vigorously consume the increased biomass of shrub crowns, and are difficult to control. Later work demonstrated that conversion of natural vegetation to timber plantations led to physical damage to the soil and increased erosion after fires. For example, 6 tonnes of soil per hectare was lost following fires in pine plantations 
Table 2 Weather conditions at 1400 hours on the days of the 2017 Knysna Fires, and the percentage of days that these (or more extreme) conditions occurred in the long-term record at George (since 1943) and Knysna (since 1997)

\begin{tabular}{|c|c|c|c|c|c|c|c|c|c|c|c|c|c|}
\hline \multirow[t]{2}{*}{2017 date } & \multicolumn{7}{|c|}{ Weather variables, fire danger, and drought indices } & \multicolumn{6}{|c|}{$\begin{array}{l}\text { Percentage of days that these (or worse) conditions occurred in the } \\
\text { historic record }\end{array}$} \\
\hline & $\begin{array}{l}\text { Rainfall } \\
(\mathrm{mm})\end{array}$ & $\begin{array}{l}\text { Temp. } \\
\left({ }^{\circ} \mathrm{C}\right)\end{array}$ & $\begin{array}{l}\text { Humidity } \\
(\%)\end{array}$ & $\begin{array}{l}\text { Wind } \\
\left(\mathrm{m} \mathrm{s}^{-1}\right)\end{array}$ & $\mathrm{FDI}$ & $\mathrm{DF}$ & KBDI & Temp. & Humidity & Wind & FDI & DF & $\mathrm{KBDI}$ \\
\hline \multicolumn{14}{|l|}{ George } \\
\hline 06 Jun & 0.0 & 31.2 & 14 & 7.5 & 38.3 & 9.3 & 91.4 & 0.90 & 0.86 & 8.85 & 0.10 & 0.45 & 0.96 \\
\hline 07 Jun & 0.0 & 18.6 & 30 & 13.8 & 24.5 & 9.3 & 91.8 & 56.08 & 5.78 & 0.19 & 0.84 & 0.45 & 0.96 \\
\hline 08 Jun & 0.0 & 10.5 & 68 & 8.4 & 3.2 & 9.3 & 91.9 & 98.83 & 61.42 & 6.55 & 20.98 & 0.45 & 0.96 \\
\hline 09 Jun & 0.0 & 15.9 & 41 & 3.9 & 6.7 & 9.3 & 92.2 & 81.62 & 13.17 & 49.25 & 9.35 & 0.45 & 0.78 \\
\hline 10 Jun & 0.1 & 22.4 & 31 & 11.1 & 21.5 & 9.3 & 92.8 & 21.82 & 6.75 & 1.02 & 1.26 & 0.45 & 0.78 \\
\hline 11 Jun & 0.0 & 18.4 & 48 & 4.8 & 6.2 & 9.3 & 93.2 & 56.08 & 21.60 & 34.00 & 9.35 & 0.45 & 0.78 \\
\hline \multicolumn{14}{|l|}{ Knysna } \\
\hline 06 Jun & 0.0 & 34.1 & 11 & 2.1 & 32.0 & 10.0 & 149.7 & 0.76 & 0.08 & 59.08 & 0.05 & 0.91 & 0.53 \\
\hline 07 Jun & 0.0 & 18.8 & 35 & 10.5 & 16.9 & 10.0 & 150.0 & 70.63 & 6.05 & 0.08 & 0.94 & 0.91 & 0.49 \\
\hline 08 Jun & 3.4 & 11.4 & 67 & 5.7 & 2.6 & 8.9 & 150.0 & 99.43 & 66.46 & 5.15 & 38.60 & 8.19 & 0.49 \\
\hline 09 Jun & 0.0 & 20.4 & 22 & 1.8 & 12.6 & 9.4 & 150.3 & 55.20 & 1.67 & 75.77 & 2.06 & 4.65 & 0.46 \\
\hline 10 Jun & 0.0 & 23.3 & 29 & 4.5 & 14.6 & 10.0 & 150.7 & 32.68 & 3.70 & 11.35 & 1.39 & 0.91 & 0.45 \\
\hline 11 Jun & 0.0 & 20.3 & 46 & 1.4 & 5.7 & 10.0 & 151.0 & 57.96 & 15.35 & 90.13 & 9.18 & 0.91 & 0.44 \\
\hline
\end{tabular}

Percentages $\leq 0.2$ are in boldface to indicate extreme conditions. Temp. = temperature; FDI = McArthur Forest Fire Danger Index; DF = drought factor; and KBDI = Keetch Byram Drought Index (Keetch and Byram 1968; Noble et al. 1980)

compared to 0.1 tonnes of soil per hectare following fire in adjacent fynbos (Scott et al. 1998). A further study (van Wilgen and Scott 2001) compared soil damage following fires in vegetation that had been invaded to different degrees on the Cape Peninsula. This study found that the degree of invasion was correlated with the physical damage to the soil, and this was especially marked between sites that were uninvaded, or lightly invaded, compared to heavily invaded sites. Our findings provide further evidence in support of contentions that invasion of natural fynbos by alien trees and shrubs, or their conversion to plantations, could result in increases in quantities of fuels consumed and thus fire severity, which is a measure of fire effects (Keeley 2009). Fire intensity, on the other hand, is a measure of the rate at which energy is released during a fire (Byram 1959, Keeley 2009). Although we could not account for the rate of biomass consumption (which likely differs between fuels of different structures) by using satellite-derived products, we showed that biomass consumed was higher in vegetation in which invasive alien trees dominated than in uninvaded shrublands. Increases in biomass consumed will almost certainly increase fire intensity, so we conclude that changes in vegetation cover from natural to invaded shrublands, or to plantations of invasive alien trees (which collectively accounted for more than half of the total burned area), would have led to fires of higher severity, and potentially higher intensity. In the case of the 2017 Knysna Fires, compound effects of large areas of invasive alien vegetation that burned with increased severity and potentially at higher intensities than natural fynbos ought to have increased the severity of the fires overall.

\section{Frequency of occurrence of severe fire weather}

The 2017 Knysna Fires were associated with very high, but not unprecedented, fire danger weather. Given its coastal location and associated temperate climate, the study area is mostly characterized by low fire danger conditions ( $87 \%$ of days), while very high fire danger ratings are a rare occurrence $(<1 \%$ of days; Kraaij et al. 2013b). Despite this, the southern Cape coastal region has experienced at least eight very large (>10 $000 \mathrm{ha})$ fires since the 1980s, three of which have been $>20000$ ha in extent, with the largest at approximately 42000 ha (Kraaij et al. 2013c). The largest fires on record in the region (since the 1980s) have furthermore been associated with variable, rather than consistently extreme, fire danger conditions (Kraaij et al. 2013b). In considering more distant history, Brown (1875) reports that an extensive fire,

...originating in different centres, and spreading each in its own locality, occurred on the $9^{\text {th }}$ of February 1869, when a tract of country 400 miles long and varying in breadth from 15 to 150 miles, was desolated by a fire unparalleled in the annals of the [Cape] colony. 


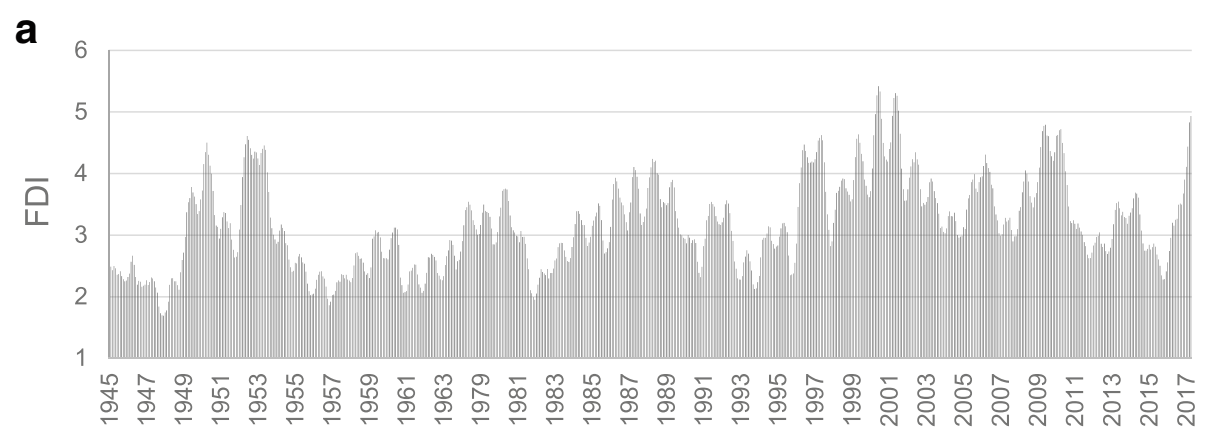

b
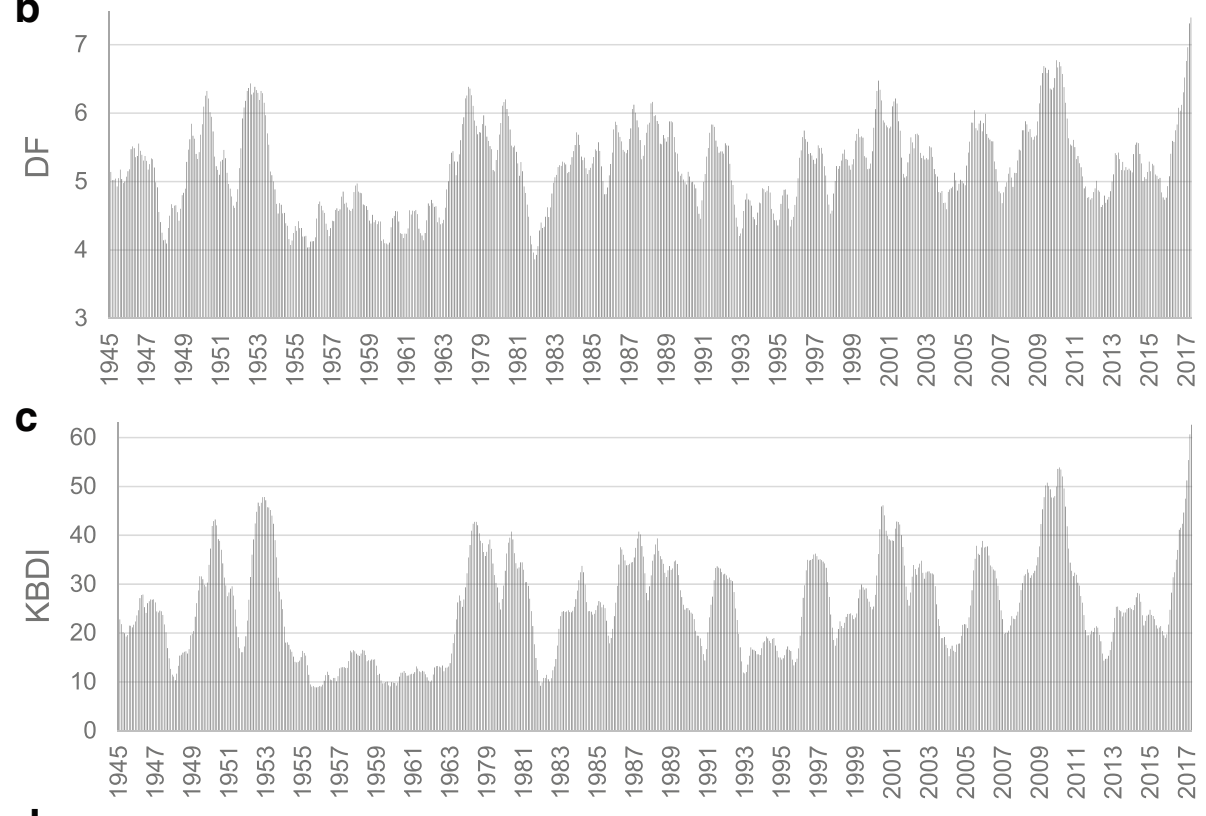

d

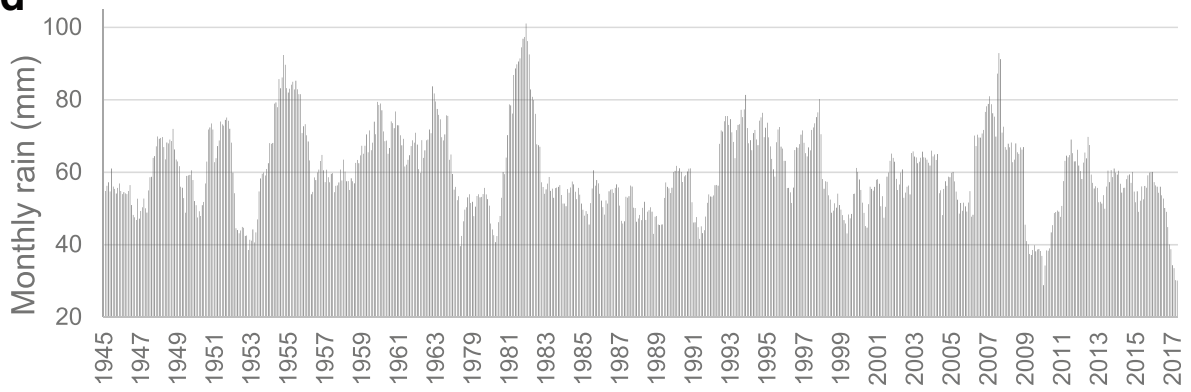

Fig. 4 Eighteen-month running means over the long-term (since 1943; at George) of the (a) McArthur Forest Fire Danger Index, FDI; (b) the drought factor, DF; (c) the Keetch Byram Drought Index, KBDl; and (d) monthly rainfall

The extensive 1869 fire, which covered over 3 million ha, overlapped with the area burned in the 2017 Knysna Fires. Accounts of the 1869 fire, such as that of Brown (1875), describe substantial loss of human life (almost 100 people are listed), and destruction of infrastructure, livestock, and wildlife. The weather conditions of the 1869 fire, almost 150 years before the 2017 Knysna Fires, occurred in conditions described as, "unusually hot and dry for the previous six weeks" (Brown 1875).
Within the historical context of the region, the 2017 Knysna Fires were thus not unprecedented in extent or in terms of the weather conditions on the days of the fires. These weather conditions, although rare, arguably cannot be attributed to global changes in climate. However, the likelihood of extreme fire danger conditions (and extreme fires) is expected to increase given that average fire danger weather has increased significantly in severity (due to increasing temperature and decreasing humidity) over the 
past 70 years in the region (Kraaij et al. 2013b). Unlike the short-term weather conditions, the prolonged drought preceding the 2017 Knysna Fires was unprecedented in the 70-year climatic record for the region and is deemed to have contributed greatly to the spread and severity of the fires. Extreme fire events (high-impact mega-fires) or anomalous areas burned in other parts of the world have similarly been associated with extreme drought and fire danger weather conditions (Dimitrakopoulos et al. 2011, Williams 2013, Keeley and Syphard 2017).

\section{Conclusions}

Changes in land use in the Knysna region have included afforestation of native fynbos shrubland vegetation with non-native pine trees, associated invasion of shrublands by pine trees spreading from plantations, and protection of fire-prone shrublands from fire. All of these changes have led to increases in fuel loads across the region. Growth in the human population has been accompanied by development in rural areas and an increase in the urban-wildland interface, increasing the risk of exposure to wildfires. These factors, combined with very high fire danger weather conditions, preceded by an unprecedented drought, led to the destructive wildfires in 2017. Events like these are infrequent, and people can quickly lose interest in implementing fire-wise practices and become increasingly willing to place developments in high-risk areas in the long inter-fire periods. Potentially useful responses could include the re-introduction of programs of prescribed burning in addition to fire suppression in key areas, effective programs to control the spread of invasive alien plants, a re-examination of the economic and ecological sustainability of commercial planting of invasive alien trees in fire-prone areas, and stricter regulation of residential and other development along the urban-wildland interface.

\section{Acknowledgements}

Weather data were made available by the South African Weather Service, and satellite imagery by the European Space Agency Scientific Data Hub.

\section{Funding}

This study was funded by Nelson Mandela University, the DST-NRF Centre of Excellence for Invasion Biology, the Council for Scientific and Industrial Research, South African National Parks, and the National Research Foundation of South Africa (grant 109467 to BWVW). None of the funding bodies played any role in the design of the study, or collection, analysis, or interpretation of data, or in writing the manuscript.

\section{Availability of data and materials}

Please contact author for data requests.

\section{Authors' contributions}

TK led the study and contributed to data collection, analysis, and interpretation, and co-wrote the paper. JAB and JA provided data and assisted with analyses. LV was responsible for analysis of remotely sensed data. BWVW collaborated in the design of the study, assisted with data interpretation, and co-wrote the paper. All authors read and approved the final manuscript.

\section{Authors' information}

T Kraaij is a lecturer and researcher in the field of vegetation ecology (ORCID 0000-0002-8891-2869); JA Baard is an ecologist and GIS practitioner; J Arndt is a postgraduate student in geography and computational sciences; $L$ Vhengani is a satellite imagery technician; and BW van Wilgen is a professor in fire ecology and invasive alien plant biology (ORCID 0000-0002-1536-7521).

Ethics approval and consent to participate

Not applicable.

\section{Consent for publication}

Not applicable.

Competing interests

The authors declare that they have no competing interests.

\section{Publisher's Note}

Springer Nature remains neutral with regard to jurisdictional claims in published maps and institutional affiliations.

\section{Author details}

${ }^{1}$ School of Natural Resource Management, Nelson Mandela University, Private Bag X6531, George 6530, South Africa. ${ }^{2}$ South African National Parks, Garden Route Scientific Services, P.O. Box 3542, Knysna 6570, South Africa. ${ }^{3}$ Department of Geography, Environment and Society, University of Minnesota Twin Cities, 267 19th Avenue S, Minneapolis, Minnesota 55455, USA. ${ }^{4}$ Meraka Institute, Council for Scientific and Industrial Research, P.O. Box 395, Pretoria 0001, South Africa. ${ }^{5}$ Centre for Invasion Biology, Department of Botany and Zoology, Stellenbosch University, Private Bag X1, Matieland 7602, South Africa.

Received: 7 February 2018 Accepted: 30 April 2018

Published online: 30 August 2018

\section{References}

Baard JA, Kraaij T (2014) Alien flora of the Garden Route National Park, South Africa. S Afr J Bot 94:51-63. https://doi.org/10.1016/j.sajb.2014.05.010

Bands D (1977) Prescribed burning in Cape fynbos catchments. In: Mooney HA and Conrad CE, technical coordinators. Proceedings of the symposium: environmental consequences of fire and fuel management in mediterranean ecosystems. USDA Forest Service General Technical Report WO-3, Washington, D.C.. p. 245-256

Bond WJ (1981) Vegetation gradients in the southern Cape mountains. Thesis, University of Cape Town, Cape Town, South Africa

Bowman D, Zhang Y, Walsh A, Williams R (2003) Experimental comparison of four remote sensing techniques to map tropical savanna fire-scars using Landsat-TM imagery. Int J Wildland Fire 12:341-348. https://doi.org/10. 1071/WF03030

Brooks ML, D'Antonio CM, Richardson DM, Grace JB, Keeley JE, Ditomaso JM, Hobbs RJ, Pellant M, Pyke D (2004) Effects of invasive alien plants on fire regimes. BioScience 54:677-688. https://academic.oup.com/bioscience/article/54/7/677/ 223532

Brown JC (1875) Hydrology of South Africa. Details of the former hydrographic conditions of the Cape of Good Hope, and causes of its present aridity, with suggestions of appropriate remedies for this aridity, Kirkcaldy: printed by John Crawford. London. p 178

Byram GM (1959) Combustion of forest fuels. In: Davis KP (ed) Forest fire: control and use. McGraw-Hill, New York, pp 61-89

Cowling RM, van Wilgen BW, Kraaij T, Britton J (2009) How no-man's land is now everyone's problem. The renowned Cape flora is everywhere in retreat as runaway pine invasions transform the Outeniqua and Tsitsikama mountains. Veld \& Flora 95:147-149

De Ronde C (2017) Knysna's great fire of 2017. SA Forestry Online. 3 July 2017. http://saforestryonline.co.za/articles/knysnas-great-fire-of-2017/. Accessed 7 Feb 2018.

Dimitrakopoulos AP, Vlahou M, Anagnostopoulou CG, Mitsopoulos ID (2011) Impact of drought on wildland fires in Greece: implications of climatic change? Clim Chang 109:331-347. https://doi.org/10.1007/s10584-011-0026-8

Drusch M, Del Bello U, Carlier S, Colin O, Fernandez V, Gascon F, Hoersch B, Isola C, Laberinti P, Martimort P, Meygret A, Spoto F, Sy O, Marchese F, 
Bargellini P (2012) Sentinel-2: ESA's Optical High-Resolution Mission for GMES Operational Services. Remote Sens Environ 120:25-36. https://doi. org/10.1016/j.rse.2011.11.026

Forsyth GG, Le Maitre DC (2015) Risk to communities at the wildland-urban interface. Report number CSIR/NRE/ECOS/ER/2015/0075/B. GEF FynbosFire project. Council for Scientific and Industrial Research, Natural Resources and the Environment, Stellenbosh

Geldenhuys C (1994) Bergwind fires and the location pattern of forest patches in the southern Cape landscape, South Africa. J Biogeogr 21:49-62. https://doi. org/10.2307/2845603

Gosling M (2017) Knysna fires: tally of destruction grows. The Citizen. 29 June 2017. https://citizen.co.za/news/south-africa/1556133/knysna-fires-tallydestruction-grows/. Accessed 6 Jan 2018.

Hall RJ, Freeburn J, De Groot W, Pritchard J, Lynham T, Landry R (2008) Remote sensing of burn severity: experience from western Canada boreal fires. Int $」$ Wildland Fire 17:476-489. https://doi.org/10.1071/WF08013

Keeley JE (2009) Fire intensity, fire severity and burn severity: a brief review and suggested usage. Int J Wildland Fire 18:116-126. https://doi.org/10.1071/WF07049

Keeley JE, Syphard AD (2017) Different historical fire-climate patterns in California. Int J Wildland Fire 26:253-268. https://doi.org/10.1071/WF16102

Keetch JJ, Byram GM (1968) A drought index for forest fire control. USDA Forest Service, Asheville

Key CH, Benson NC (1999) The Normalized Burn Ratio (NBR): a Landsat TM radiometric measure of burn severity. United States Geological Survey, Northern Rocky Mountain Science Center, Bozeman

Kraaij T, Baard JA, Cowling RM, van Wilgen BW, Das S (2013b) Historical fire regimes in a poorly understood, fire-prone ecosystem: eastern coastal fynbos. Int J Wildland Fire 22:277-287. https://doi.org/10.1071/WF11163

Kraaij T, Baard JA, Rikhotso DR, Cole NS, van Wilgen BW (2017) Assessing the effectiveness of invasive alien plant management in a large fynbos protected area. Bothalia Afr Biodivers Conserv 47(2):a2105. https://doi. org/10.4102/abc.v47i2.2105

Kraaij T, Cowling RM, van Wilgen BW (2011) Past approaches and future challenges to the management of fire and invasive alien plants in the new Garden Route National Park. S Afr J Sci 107(9/10):Art. \#633. https://doi.org/10. 4102/sajs.v107ig/10.633

Kraaij T, Cowling RM, van Wilgen BW (2013c) Lightning and fire weather in eastern coastal fynbos shrublands: seasonality and long-term trends. Int J Wildland Fire 22:288-295. https://doi.org/10.1071/WF11167

Kraaij T, Cowling RM, van Wilgen BW, Schutte-Vlok A (2013a) Proteaceae juvenile periods and post-fire recruitment as indicators of minimum fire return interval in eastern coastal fynbos. Appl Veg Sci 16:84-94. https://doi.org/10. 1111/j.1654-109X.2012.01209.x

Kraaij T, van Wilgen BW (2014) Drivers, ecology, and management of fire in fynbos. In: Allsopp N, Colville JF, Verboom GA (eds) Fynbos: ecology, evolution, and conservation of a megadiverse region. Oxford University Press, Oxford, pp 47-72

Le Maitre DC, van Wilgen BW, Chapman RA, McKelly DH (1996) Invasive plants and water resources in the Western Cape Province, South Africa: modelling the consequences of a lack of management. J Appl Ecol 33:161-172. https://doi.org/10.2307/2405025

López García MJ, Caselles V (1991) Mapping burns and natural reforestation using thematic Mapper data. Geocarto Int 6:31-37. https://doi.org/10.1080/ 10106049109354290

Malenovský Z, Rott H, Cihlar J, Schaepman ME, García-Santos G, Fernandes R, Berger M (2012) Sentinels for science: potential of Sentinel-1, -2 , and -3 missions for scientific observations of ocean, cryosphere, and land. Remote Sens Environ 120:91-101. https://doi.org/10.1016/j.rse.2011.09.026

Mandle L, Bufford JL, Schmidt IB, Daehler CC (2011) Woody exotic plant invasions and fire: reciprocal impacts and consequences for native ecosystems. Biol Invasions 13:1815-1827. https://doi.org/10.1007/s10530-011-0001-3

Miller JD, Knapp EE, Key CH, Skinner CN, Isbell CJ, Creasy RM, Sherlock JW (2009) Calibration and validation of the Relative differenced Normalized Burn Ratio (RdNBR) to three measures of fire severity in the Sierra Nevada and Klamath Mountains, California, USA. Remote Sens Environ 113:645-656. https://doi. org/10.1016/j.rse.2008.11.009

Miller JD, Thode AE (2007) Quantifying burn severity in a heterogeneous landscape with a relative version of the delta Normalized Burn Ratio (dNBR). Remote Sens Environ 109:66-80. https://doi.org/10.1016/j.rse.2006.12.006

Müeller-Wilm U (2016) Sentinel-2 MSI-Level-2A prototype processor installation and user manual. Telespazio VEGA Deutschland GmbH, Darmstadt
Noble IR, Bary GAV, Gill AM (1980) McArthur's fire danger meters expressed as equations. Austral Ecol 5:201-203. https://doi.org/10.1111/j.1442-9993.1980.tb01243.x

Pauchard A, Garcia RA, Pena E, Gonzalez C, Cavieres LA, Bustamante RO (2008) Positive feedbacks between plant invasions and fire regimes: Teline monspessulana (L.) K. Koch (Fabaceae) in central Chile. Biol Invasions 10:547553. https://doi.org/10.1007/s10530-007-9151-8

Preston G (2017) Knysna fires: five factors that produced the perfect inferno. The Botanical Society of South Africa http://www.botanicalsociety.org.za/ BranchesAndGardens/Quick\%20Downloads/2017\%20Guy\%20Preston Knysna\%20Fires\%205\%20factors\%20that\%20the\%20Perfect\%20Inferno.pdf. Accessed 15 Dec 2017

Quinn RD (1994) Animals, fire, and vertebrate herbivory in Californian chaparral and other mediterranean-type ecosystems. In: Moreno JM, Oechel WC (eds) The role of fire in mediterranean-type ecosystems. Springer-Verlag, New York, pp 46-78. https://doi.org/10.1007/978-1-4613-8395-6_4

Radeloff VC, Hammer RB, Stewart SI, Fried JS, Holcomb SS, McKeefry JF (2005) The wildland-urban interface in the United States. Ecol Appl 15:799-805. https://doi.org/10.1890/04-1413

Riggan PJ, Franklin SE, Brass JA, Brooks FE (1994) Perspectives on fire management in mediterranean ecosystems of southern California. In: Moreno JM, Oechel WC (eds) The role of fire in mediterranean-type ecosystems. Springer-Verlag, New York, pp 140-162. https://doi.org/10.1007/ 978-1-4613-8395-6_8

San-Miguel-Ayanz J, Moreno JM, Camia A (2013) Analysis of large fires in European Mediterranean landscapes: lessons learned and perspectives. For Ecol Manag 294:11-22. https://doi.org/10.1016/j.foreco.2012.10.050

Scott DF, Versfeld DB, Lesch W (1998) Erosion and sediment yield in relation to afforestation and fire in the mountains of the Western Cape Province, South Africa. S Afr Geogr J 80:52-59. https://doi.org/10.1080/03736245. 1998.9713644

Southey D (2009) Wildfires in the Cape Floristic Region: exploring vegetation and weather as drivers of fire frequency. Thesis, University of Cape Town, Cape Town

Stehle T (2017) Knysna's great fire of 2017. SA Forestry Online. 3 July 2017. http://saforestryonline.co.za/articles/knysnas-great-fire-of-2017/. Accessed 23 Jan 2018.

Syphard AD, Keeley JE, Pfaff AH, Ferschweiler K (2017) Human presence diminishes the importance of climate in driving fire activity across the United States. PNAS 114:13750-13755. https://doi.org/10.1073/pnas.1713885114

Van der Merwe M (2017) Knysna blaze: hunt is on for the fire starter. Daily Maverick. 15 August 2017. https:/www.dailymaverick.co.za/article/2017-08-15-knysnablaze-hunt-is-on-for-the-fire-starter/\#.WnreEehuaUk. Accessed 20 Sept 2017.

van Wilgen BW (1982) Some effects of post-fire age on the above-ground plant biomass of fynbos (macchia) vegetation in South Africa. J Ecol 70:217-225. https://doi.org/10.2307/2259874

van Wilgen BW (2009) The evolution of fire and invasive alien plant management practices in fynbos. S Afr J Sci 105:335-342

van Wilgen BW, Higgins KB, Bellstedt DU (1990) The role of vegetation structure and fuel chemistry in excluding fire from forest patches in the fire-prone fynbos shrublands of South Africa. J Ecol 78:210-222. https:/doi.org/10.2307/2261046

van Wilgen BW, Richardson DM (1985) The effects of alien shrub invasions on vegetation structure and fire behaviour in South African fynbos shrublands: a simulation study. J Appl Ecol 22:955-966. https://doi.org/10.2307/2403243

van Wilgen BW, Scott DF (2001) Managing fires on the Cape Peninsula of South Africa: dealing with the inevitable. J Mediterr Ecol 2:197-208

Vegter I (2017) The great Knysna fire was not caused by climate change. Daily Maverick. 19 June 2017. https://www.dailymaverick.co.za/ opinionista/2017-06-19-the-great-knysna-fire-was-not-caused-by-climatechange/\#.Wnq1-OhuaUk. Accessed 6 Jan 2018.

Versfeld DB, van Wilgen BW (1986) Impact of woody aliens on ecosystem properties. In: Macdonald IAW, Kruger FJ, Ferrar AA (eds) The ecology and management of biological invasions in Southern Africa. Oxford University Press, Cape Town, pp 239-246

Vlok JHJ, Euston-Brown DIW, Wolf T (2008) A vegetation map for the Garden Route Initiative. Unpublished 1:50 000 maps and report. CAPE task team, South African National Parks, Knysna

Vonberg, J., and V. Cotovio. 2017. Portugal and Spain wildfires kill at least 39 people. Central News Network. http://edition.cnn.com/2017/10/16/europe/ portugal-spain-wildfires/index.html. Accessed 17 Dec 2017.

Vromans DC, Maree KS, Holness S, Job N, Brown AE (2010) The Garden Route Biodiversity Sector Plan for the George, Knysna and Bitou municipalities, 
Supporting land-use planning and decision-making in Critical Biodiversity Areas and Ecological Support Areas for sustainable development. Garden Route Initiative, South African National Parks, Knysna

Williams J (2013) Exploring the onset of high-impact mega-fires through a forest land management prism. For Ecol Manag 294:4-10. https://doi.org/10.1016/j. foreco.2012.06.030

Submit your manuscript to a SpringerOpen ${ }^{\mathcal{O}}$ journal and benefit from:

- Convenient online submission

- Rigorous peer review

- Open access: articles freely available online

- High visibility within the field

- Retaining the copyright to your article

Submit your next manuscript at $\boldsymbol{\sim}$ springeropen.com 